\title{
A KÖLTSÉGVETÉS NYILVÁNOSSÁGA - KORRUPCIÓ, ÁTLÁTHATÓSÁG, ELSZÁMOLTATHATÓSÁG*
}

\author{
Péteri Gábor ${ }^{40}$

\section{Korrupció van}

Ma a közpénzek felhasználásáról már szinte mindenkinek csak a korrupció jut az eszébe. Valóban nehéz más ügyet kapcsolni ehhez a költségvetésböl finanszirozott beruházások kivitelezöiről vagy az üzemeltetöi szerzödések beszállitóiról szóló történeteket hallva. Az esetek, példák pedig gyakoriak, elég csak az Átlátszó.hu blogot, vagy más civil szervezet, kutatócsoport hireit olvasni.

Közösségi forrásokból személyes elönyökhöz jutni viszonylag egyszerü: ha monopolizált a döntéshozatal és széleskörü önállósággal rendelkezik a pénzek felett diszponáló szervezet, vagy személy, akkor nagy a korrupciós kockázat. Ezt csökkenteni csak olyan eszközökkel lehet, amelyek ellenörizhetövé vagy elszámoltathatóvá teszik magát a politikusokat és az általuk irányitott igazgatási rendszert. Ez azonban, amint azt Horváth M. Tamás a korábbi tanulmányában megírta ${ }^{41}$, már nem megy csak az állam szük, jogi megközelitésére építve. A közpolitika-alakitás, a gazdálkodási érdekeltség és szabályozás ugyanennyire befolyásolják a korrupció mértékét.

Elég csak arra gondolni, hogy az EU-s csatlakozás időszakában is elhangzottak olyan érvek, hogy a többszintü pénzelosztási rendszer mennyire rossz ösztönzőket fog eredményezni központi és helyi szinten. Ma már láthatjuk, hogy valóban egy önkormányzat fejlesztési politikája már szinte teljesen a támogatásoktól függ. Kölcsönös közösségi, személyes és vállalkozói előnyökről, mint helyi fejlesztési erőforrásokról alig van szó.

A finanszírozási-érdekeltségi viszonyok mellett a korrupció fenti képletét természetesen a társadalom türőképessége, az általános értékrend is alakítja. Nem egy politikai változás indult ki abból, hogy az emberek úgy érezték, ami elég az elég, alapjaiban kell a rendszert átalakítani. Az más kérdés, hogy ezek mennyire hoztak tartós változásokat, de például az egy évtizeddel ezelőtti grúziai korrupció ellenes kormányzati fellépés eredményei máig hatnak és a térségben követendő példaként tekintenek rájuk.

A korrupció korlátozásához tehát a jogi előírások, eljárási szabályok szükséges, de nem elégséges eszközök. A közbeszerzési eljárásokon, a számvevőszéki ellenőrzés technikáin túl a közszektoron belüli elszámoltathatóság tartalmi szabályait is át kell alakítani ahhoz, hogy valamilyen eredményt el lehessen érni. Itt most ennek a tágan értelmezett elszámoltathatósági rendszernek egyik kulcsfontosságú eleméről, a költségvetési információk nyilvánosságáról lesz szó.

\section{Átlátható a közszektort!}

A közszolgáltatások költségeinek és finanszírozási forrásainak nyilvánossága nélkül nem lesz elszámoltatható az ezekről döntő választott testület. Az összefüggés egyszerü, de kérdés, hogy

\footnotetext{
A tanulmány a Magyar Tudományos Akadémia és a Debreceni Egyetem Állam- és Jogtudományi Kar közös, MTA-DE Közszolgáltatási Kutatócsoportjának a Területi közszolgáltatások szabályozásai címü projektje keretében készült. A projekt leírására 1.: Horváth M.T.: Szempontok a területi közszolgáltatások regulációs változásainak vizsgálatához. In: HMT (szerk.) Kilengések. Közszolgáltatási változások. Budapest: Dialóg Campus, 2013. 9-25.

${ }^{40}$ Péteri GáborCSc., tanácsadó, LGID Ltd.

${ }^{41}$ HoRvÁTH M. Tamás: Kié a közjog? In: Közjavak, 1. évfolyam, 1. szám, 2015 július-szeptember, 4-7.
} 
ezt a szabályt hogyan lehet a költségvetési gyakorlatba beépíteni. A nemzetközi pénzügyi szervezetek már több mint egy évtizede megfogalmazták a maguk elvárásait. Így a költségvetési gyakorlat számára legfontosabbak talán az IMF költségvetési átláthatósági szabályrendszer ${ }^{42}$ elvei és módszerei. Ez a kódex a tervezés, beszámolás és költségvetési kockázatkezelés nagy témakörei szerint fogalmazza meg az elvárásait. Közöttük a helyi önkormányzatok pénzügyi helyzetére vonatkozó részletes információk gyüjtésének és nyilvánosságra hozatalának követelményét. Ezen kívül más donor szervezetek is sokféle gyakorlatias programot indítottak a jobb pénzügyi átláthatóság érdekében (ilyen például a GIFT program ${ }^{43}$ ).

Érdekes módon ezek a befolyásos pénzügyi szervezetek azonban csak követték azokat a civil mozgalmakat, amelyek valójában elkezdték a korrupció és a nyilvánosság ügyét exponálni. Sőt ma már helyi, országos és nemzetközi szinten is talán inkább ők határozzák meg a költségvetési nyilvánosság ügyeit, fejlesztik a költségvetési gyakorlatot, támogatják a független és a kormányzati szervezeteket is.

Például az egyik legnagyobb globális program a Nyitott Kormányzati Együttmüködés ${ }^{44}$ elindítói is ilyen nem-kormányzati szervezetek voltak. Közöttük egyik meghatározó a nemzetközi költségvetési partnerség, amely folyamatosan fejleszti a költségvetési nyilvánosságot mérő indikátorait és ma már közel száz ország gyakorlatát képes objektíven értékelni és összehasonlítani. A program jelmondata jól tükrözi a nyilvánosság célját: "Open Budgets. TransformLives.", azaz nyisd meg a költségvetést és ezzel alakítsd át az életlehetöségeket.

Magyarország is tagja a Nyitott Kormányzati Együttműködésnek (OGP). 2012 óta már a második fordulóban fogalmazza meg a kormányzat a vállalásait. ${ }^{45}$ Ezek fontos része volt már 2013-ban is a költségvetési adatok nyilvánosságának javítása, majd ennek következményeként egy kormányhatározat szerint 2016 márciusáig a „közadatok újrahasznosítását támogató nemzeti közadatportál" létrehozására is sor kerül.

Angol mintára már több ország, így Szlovákia, Macedónia is létrehozta a kormányzati adatokhoz való hozzáférés internetes pontját, ami nagyban egyszerüsíti és segíti azok munkáját, akiknek ilyen információkra van szükségük. Remélhetőleg így nálunk is megvalósul ez az OGP célkitüzés és ahogy az akcióterv rögzíti valóban elérhetők és újrahasznosíthatók lesznek a nyers adatok.

A Nyitott Kormányzati Együttmüködés programja a civil szféra és a kormányzati szervek együttmüködésére épül. Ez a kapcsolat azonban nem volt mind a két fél számára megfelelö, például a trafikbotrány, a közérdekü információs kérelmek elbírálásának újraszabályozása után négy szervezet tiltakozásként kilépett a közös OGP munkacsoportból.

Időközben egyébként lezajlott a program külső, független értékelése is. ${ }^{46} \mathrm{Ez}$ többek között megállapította, hogy a költségvetés nyilvánosságára vonatkozó korábbi vállalások egy részét a következő akciótervbe is be kell építeni. Ez itt elsősorban a közpénzek lakossági tájékoztatására és a központi költségvetés részletesebb funkcionális (két számjegyü mélységü COFOG kategóriák szerinti) adatainak közreadását jelenti. Ebből tudhatnánk meg, hogy valójában mire mennyit költ a kormányzat.

A program része volt a költségvetés nyitottságát mérő vizsgálat is. ${ }^{47}$ Ebből többek között kiderült, hogy a költségvetési adatokat a felhasználók felerészben szerzik meg a kormányzati honlapokról. Az esetek negyedében csak a parlamenti előterjesztések szolgálnak forrásként, illetve más csatornákon keresztül (EU-s honlapok, közlönyök, stb.) jutnak hozzá az információkhoz.

\footnotetext{
${ }^{42}$ http://blog-pfm.imf.org/files/ft-code.pdf (letöltés: 2015.november 12.)

${ }^{43} \mathrm{http}: / / \mathrm{www}$.fiscaltransparency.net/ (letöltés: 2015 .november 12.)

44 http://www.opengovpartnership.org/ (letöltés: 2015.november 12.)

$45 \mathrm{http} / / /$ korrupciomegelozes.kormany.hu/nyilt-kormanyzati-egyuttmukodes (letöltés: 2015.november 12.)

${ }^{46} \mathrm{http}: / /$ www.budapestinstitute.eu/uploads/OGP Progress in Hungary HU.pdf (letöltés: 2015.november 12.)

${ }^{47}$ http://kfib.hu/hu/obs2015 (letöltés: 2015.november 12.)
} 
Ennek egyik formája a közérdekű adatok igénylése, amit viszont a legutóbbi változásokkal tovább nehezített a szabályozás. Így megszűnt az anonim adatigénylés, nem lehet ismételten beadni egy igényt, a költségek átháríthatók az igénylöre, háttér- és döntés-elökészítő anyagok kiadása megtagadható. ${ }^{48}$

A kormányzat és a civil szektor közötti kapcsolat nem mindenhol alakul így, mint nálunk. Amint arról már volt szó egymástól is tanulnak és egy sajátos szakmai versengés is tapasztalható. Például a közpénzekkel való gazdálkodás és elszámoltathatóság általános minősítési rendszere kormányzati információk alapján, de ugyanolyan független értékelési módszertant alakított ki, mint a témával foglalkozó nem-kormányzati szervezetek. A civil szervezetek is kilépnek az egyszerü kritikusi szerepkörből és igyekeznek a kormányzati gyakorlati munkát támogató technikákat kifejleszteni. Ilyen például az Integrity Action egyik módszere, amelyik lakossági információkat gyüjtve igyekszik a helyi közszolgáltatások megszervezését támogatni. ${ }^{49}$

\section{Központi vagy helyi kontroll?}

A kormányzati elszámoltathatóság egyik alapkérdése, hogy vajon a decentralizációval javul-e a közösségi döntések ellenőrizhetősége és kisebb lesz-e a korrupciós kockázat, vagy sem. Különböző módszereket alkalmazó kutatások eltérő eredményekre jutottak, hiszen egy ilyen erősen társadalmi beágyazódottságú jelenségnél nem mindegy, hogy mit és hogyan is vizsgálunk. Általában elfogadott, hogy a helyi önkormányzatiság kiépítésével együtt járó demokratizálódás növeli a helyi elszámoltathatóságot. Természetesen tudjuk, hogy a társadalmi közeg sajátosságai szerint kialakulhatnak helyi függelmi viszonyok, ahol az elit irányít és nincs hathatós civil ellenőrzés.

Viszont egy átfogó több országra kiterjedő vizsgálat szerint a decentralizációval csökken a korrupció mértéke. ${ }^{50}$ Ennek az alapja, hogy erösebb a szereplök közötti versengés és helyben könnyebb alapvető információkhoz hozzájutni (pl. kiderül a hirtelen, látványos meggazdagodás). Látszólag nőhet a korrupciós esetek darabszáma, de ez nem feltétlenül jelenti azt, hogy a közpénzek nagyobb része kerülne így veszélybe.

Ez utóbbira talán a legjobb példa az M7-es autópályán megépült Köröshegyi völgyhíd lehet. Amint az ÁSZ jelentésébő $1^{51}$ is kiderült erre a beruházásra nem volt szükség, pontosabban nem ott és nem annyiért kellett volna megépíteni. Egy ilyen túlárazott központi beruházással szembeállítva az összes önkormányzati áteresz-építést, hídfelújítást, nyilvánvaló, hogy a kétféle korrupciós veszteség nagyságrendekkel kisebb a helyi költségvetésben. Ha tehát az államháztartás kiadásainak nagyobb része teljesül helyi kontroll mellett, akkor javul az átláthatóság és így nő az elszámoltathatóság.

Ez az állítás úgy is megfogalmazható, hogy a központosítottabb rendszerekben még jobban felértékelődik az információk nyilvánossága. Itt ugyanis nagyobb jelentősége van a fogyasztótól és választott testületektől távoli központi forrásoknak, programoknak, támogatási csomagoknak. Általában a közszolgáltatások központosításával újfajta szabályozásiellenőrzési mechanizmusokat kell kialakítani. A városi kórház, a saját fenntartású iskola, az ismert szociális ellátó intézmény felett müködik a testületi kontroll. De ha ezek az intézmények egy távoli költségvetésből kapott forrásokból és más által ellenőrzött módon gazdálkodnak, akkor sem a helyi testületi, sem a fogyasztói ellenőrzés nem fog úgy müködni, mint ha mindezek helyiek lennének.

\footnotetext{
48 http://tenytar.blog.hu/2015/07/22/ne zavarj epp lopok igy rejti el a kormany hogy mire kolti az adodat (letöltés: 2015.november 12.)

${ }^{49}$ http://www.integrityaction.org/sites/www.integrityaction.org/files/IAC 002 TheFixRate Report WEB 1.pdf (letöltés: 2015.november 12.)

${ }^{50}$ IVANYNA, M.-Shah, A. (2011): Decentralization and corruption: New cross-countryevidence, The World Bank.

${ }^{51} \mathrm{http}$ //www.asz.hu/jelentes/0813/jelentes-a-2007-ben-befejezodo-autopalya-beruhazasokellenorzeserol/0813j000.pdf (letöltés: 2015.november 12.)
} 
Példaként említhető a vízgazdálkodás új rendszere, vagy az államosított közoktatás. A vízügyben az állami és központosított megoldások csak akkor lesznek eredményesek, ha mindezek egy sokkal jobban ellenőrzött állam részeként müködnek. Ha a választói részvétel és a fogyasztói beleszólás külső kontrolljai nélkül épülnek ki az államosított megoldások, akkor valójában az olyan alapjog, mint a vízhez való jog érvényesülése helyett csak egy kevésbé hatékony közszolgáltatást kapunk.

A köznevelés központosított irányítási és finanszírozási rendszere - bár nyilvánvalóan egy politikai folyamat részeként -hasonló kockázatokkal jár. Ma az teljes mértékben állami fenntartásba és részben központilag üzemeltetett vett iskolák költségvetéséről nem sok információnk van és az is csak kétéves késéssel érhető el. Akkor még nagyobb a baj, ha nem csak a külső szakértők, kutatók, vagy a parlamenti képviselök, hanem a funkcionális minisztériumok sem tudják, hogy mi történik egy ágazat költségvetésében, mire és milyen szempontok alapján költ el egy szervezet évente több mint ötszáz milliárd forintot.

\section{Mennyibe kerül a KLIK?}

Ma két évvel az új köznevelési irányítási és finanszírozási rendszer bevezetése után jogosan feltehető az az egyszerü kérdés, hogy az iskolák állami fenntartásba vételének és a központosított tanügyirányításnak mi a költségvetési hatása. Az átszervezés egyik indoka ugyanis az volt, hogy ezzel megtakarítások érhetők el. Az ágazat kiadásain belül fontos részkérdés, hogy mennyibe kerül a Klebelsberg Intézményfenntartó Központ (KLIK) igazgatása és müködtetése?

A közoktatási ágazat átszervezése 2012-ben indul meg és a tanári bérrendszer 2013 őszétől kezdett el új formájában müködni. Az átalakulás pénzügyi elemzéséhez alapvetően három hazai információs forrásra lehet építeni, illetve még elérhetők az Eurostat funkcionális költségvetési kiadási adatai kormányzati szintenként. Az magyar adatforrások között elsődlegesek az Országgyülés irományai között fellelhető éves költségvetési előterjesztések és beszámolók mellékletei. A Magyar Államkincstár honlapján megtalálhatók a központi költségvetési intézmények, így a KLIK terv és beszámoló adatai. Valamint az ágazat oktatásstatisztikai évkönyvei is tartalmaznak intézménytípusonkénti közgazdasági bontású központi és helyi költségvetési kiadási adatokat.

A négy forrásból kigyüjthető adatokkal alapvetően két gond van. Az egyik, hogy ma 2015 végén, amikor a 2014. évi költségvetési beszámoló és a 2016. évi költségvetési tervezet már elérhető a képviselők számára, a köznevelés kiadásait az egyébként megbízható és részletes oktatásstatisztikai évkönyvekben csak 2013-ra vonatkozóan lehet megtalálni. Ezek szerint akkor 793 milliárd forint volt a köznevelési feladatokra fordított állami kiadás. A költségvetési beszámolókban szereplö központi és önkormányzati oktatási tevékenységek (F04) között elszámolt köznevelési kiadás ennek azonban már csak a fele. Az időbeli összehasonlítást nehezíti, hogy a szakképzés költségei átkerültek a minisztériumi költségvetésbe, ami az intézmény szétválasztások és a tanmühely-finanszírozás változásai miatt még bizonytalanabbá teszi ezeket az adatokat.

A másik, talán még ennél is nagyobb baj, hogy ebben a költségvetési információs rendszerben a köznevelés kiadásai egy összegben jelennek meg. Tehát nem tudjuk, hogy mi történik ebben a költségvetési „fekete dobozban”. Kevés a pénzügyi információ és az ezekkel szembeállítható teljesítménymutató. A köznevelés információs rendszeréből (KIR) ${ }^{52}$ azt még meg lehet tudni, hogy 2015 májusában a KLIK volt a fenntartója a 3582 általános iskola közül 1809-nek, vagy a 646 gimnázium közül 327-nek. De ezek költségvetési kiadásairól már nincs részletes adat. Ugyanígy az önkormányzatok által üzemeltetett intézmények költségvetését sem lehet már követni: a kiadások és bevételek beolvadnak a helyi intézményfenntartók költségvetésébe, a kiszerződött szolgáltatások megbízási díjaiban.

\footnotetext{
${ }^{52}$ http://www.oktatas.hu/kozneveles/kir (letöltés: 2015.november 12.)
} 
Az olyan költségvetési hatékonyság-elemzésekre, amelyekre korábban a decentralizált rendszerben bármelyik város, vagy több iskolával rendelkező község képes volt, ma a nyilvánosan megjelenő adatokból már nincs mód. Lehet, hogy ilyen fajlagos költségszámítások tankerületek szintjén még történnek, de mivel a rendszer központosított ez már nem valószínü, hogy beépül a döntéshozatalba.

Ha a közoktatás adatain belül a központi irányítás költségeit akarjuk megtudni, akkor az ágazati fejezet költségvetésének „18. Köznevelési feladatellátás és irányítás intézményei” címen találhatók meg a KLIK adatai. Itt azonban csak a foglalkoztatotti létszámra és a rendszeres személyi juttatásokra vonatkozóan van információ. Ezek szerint 2014-ben 1950 fö volt a köztisztviselö, kormánytisztviselő, tehát aki tanügyigazgatásban dolgozott, míg 121244 a közalkalmazott, jellemzően pedagógus. Az egyéb bérrendszerbe tartozott 4368 fő (köztük 3984 közfoglalkoztatott). Mindezek személyi kiadásai 361 milliárd forintot tettek ki a 2014. évi tényadatok szerint.

A Magyar Államkincstár költségvetési intézményi adatai között a KLIK-ről 2013. évi költségvetési előirányzat a legutolsó adat. Itt már megjelennek a bérekre rakódó járulékok, a dologi kiadások és egyéb működési, valamint fejlesztési kiadások is. Így a KLIK összes müködési kiadása már 496 milliárd forint, amihez még hozzáadódik 2,8 milliárd felhalmozási kiadás is.

Mindezekből látható, hogy az ágazat egészére kiterjedő költségvetési elemzés lehetőségei korlátozottak. A nyilvános adatok hiányával egyrészt sokat veszít az ágazat, másrészt a költségvetési politika is. A köznevelési politika külső kontrolljára vagy esetleg alternatív javaslatok kidolgozására pedig így esély sincs. 